УДК 903.27(510)

\title{
Distribution and Features of Rock Carvings in China
}

\author{
Wang Xiaokun ${ }^{\mathrm{a}}$ and Zhang Wenjing ${ }^{\mathrm{b} *}$ \\ ${ }^{a}$ Renmin University of China \\ Haidian, District Beijing, 100872, China \\ ${ }^{b}$ China Rock Art Academy \\ Xicheng District Beijing, 100031, China
}

Received 11.12.2017, received in revised form 26.01.2018, accepted 09.02.2018

Speaking about the distribution system, rock carvings in China can be divided into Northern rock carvings, Southwestern rock carvings and Southeast rock carvings. Within each region, the distribution of rock carvings has obvious similarities, and in each region rock carvings have their own characteristics that differ from other areas.

Keywords: rock carvings in China, regional distribution, comparison of features.

This article is the result of a project sponsored by the Renmin University of China for Scientific Research (funded by a special fund for basic scientific research in central universities) with a project number of $18 Y Y A 02$.

DOI: $10.17516 / 1997-1370-0224$.

Research area: culturology, history.

After several decades of research and study, the scientific community has classified a system of distribution of petroglyphs in China. Based on the geographical position, the technique of creation, the style image and the theme of the content, it is possible to divide the rock carvings in China into the Northern rock carvings, the Southwestern rock carvings and the Southeast rock carvings (Chen Zhaofu, 2008). Within each region, the distribution of rock carvings has obvious similarities, and in each region rock carvings have their own characteristics that differ from other areas

\section{Three areas of the Chinese rock carvings}

1. Distribution of rock carvings in the Northern regions

Northern rock carvings are mainly distributed in Inner Mongolia, Ningxia, Gansu, Qinghai, Xinjiang, Tibet and other territories. The Northern rock drawings depict animals that are embodied in production, lifestyle and religious beliefs. The technique of creation is mainly abrading, incising and sometimes engraving, a relatively small part of petroglyphs are made by painting (Fig. 1).

(C) Siberian Federal University. All rights reserved

* Corresponding author E-mail address: pmandryka@yandex.ru 


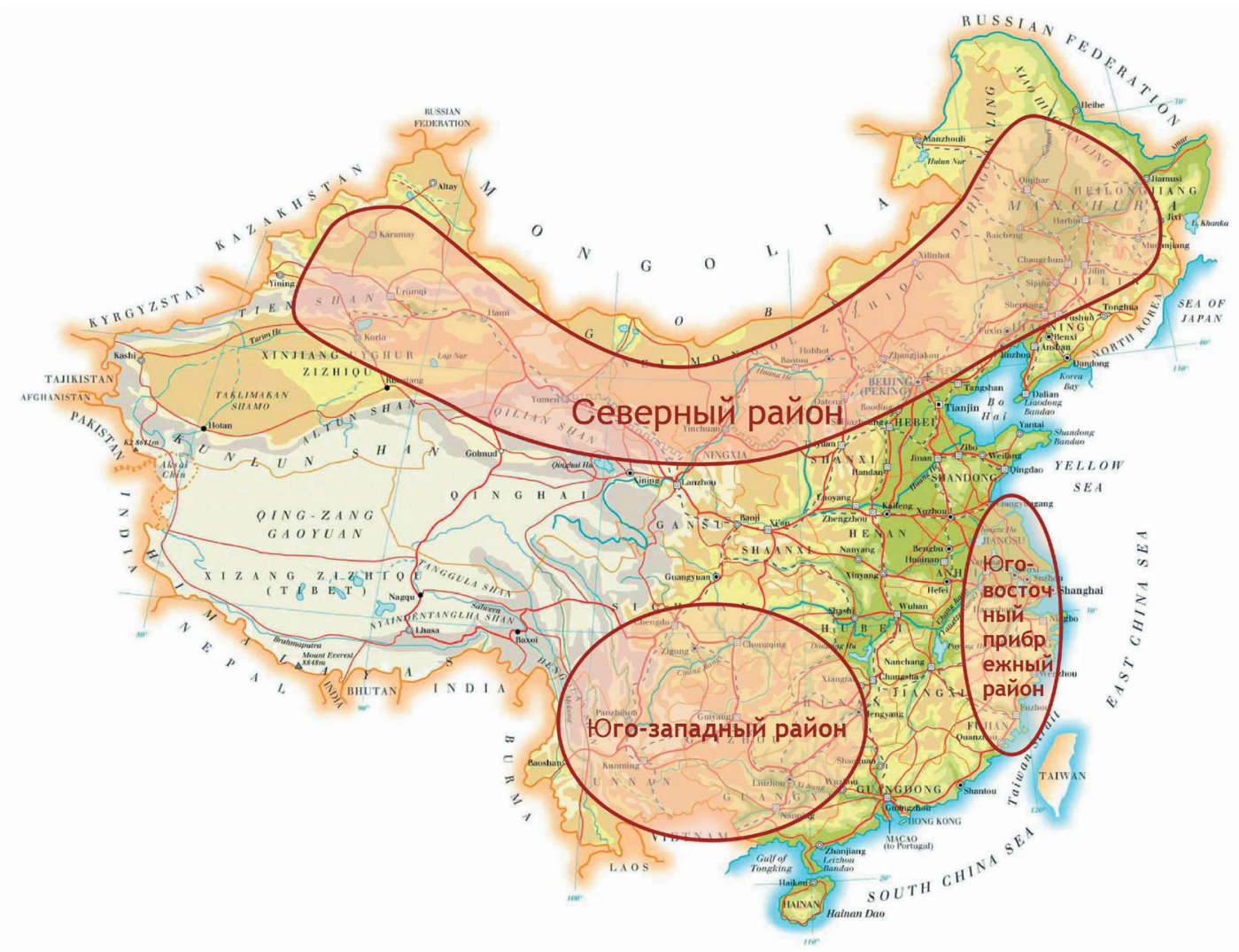

Fig. 1. Distribution of Chinese petroglyphs

Petroglyphs of the Eastern part of Inner Mongolia are mainly concentrated in the basin of the Xilamulun River in the city of Chifeng. In the urban district of Hulunbuir, the Oroqen Autonomous Banner, within Argunzuoqi and Argunyuqi the petroglyphs can be rarely seen, they are painted with a brick-red pigment, the main themes are cattle grazing and deer hunting. Locations of petroglyphs in the urban district of Chifeng are Chuangjingou, Dongmazongshan, Baichahe, Xilamulunhe, Yinhe, as well as Tucheng zi or Zhenzishan (Fig. 2).

Petroglyphs of Chuangjingou depict a person's face, the technique of creation is abrading; petroglyphs of Dongmazongshan are created by painting with a brick-red pigment, the theme of hunting and dancing predominates; among the petroglyphs of Baichahe the animals are the most common theme; the theme also includes images of a deer, a wild boar, a horse, cattle, a dog, a camel, a tiger, etc., among them deer are depicted more often, hunting and a human face are also an important part of the manifestation of the theme. In addition, there are petroglyphs with dances, as well as circles, concentric circles and other symbols. Among petroglyphs of Baichahe, animals, hunting, etc. are represented by abrading techniques; petroglyphs of dances are created by applying a brownish-red pigment. The main content of petroglyphs of Xilamulunhe is a spotted deer, a pheasant, a horse, a man, etc. Petroglyphs of Zhenzishan depict a horse, a tiger, a horseman and other images, the techniques of abrading and engraving prevail. The main content of petroglyphs of Yinhe is an image of a person's face, as well as animals and symbols. According to the studies of Zhang Songbai (Chen Zhaofu, 


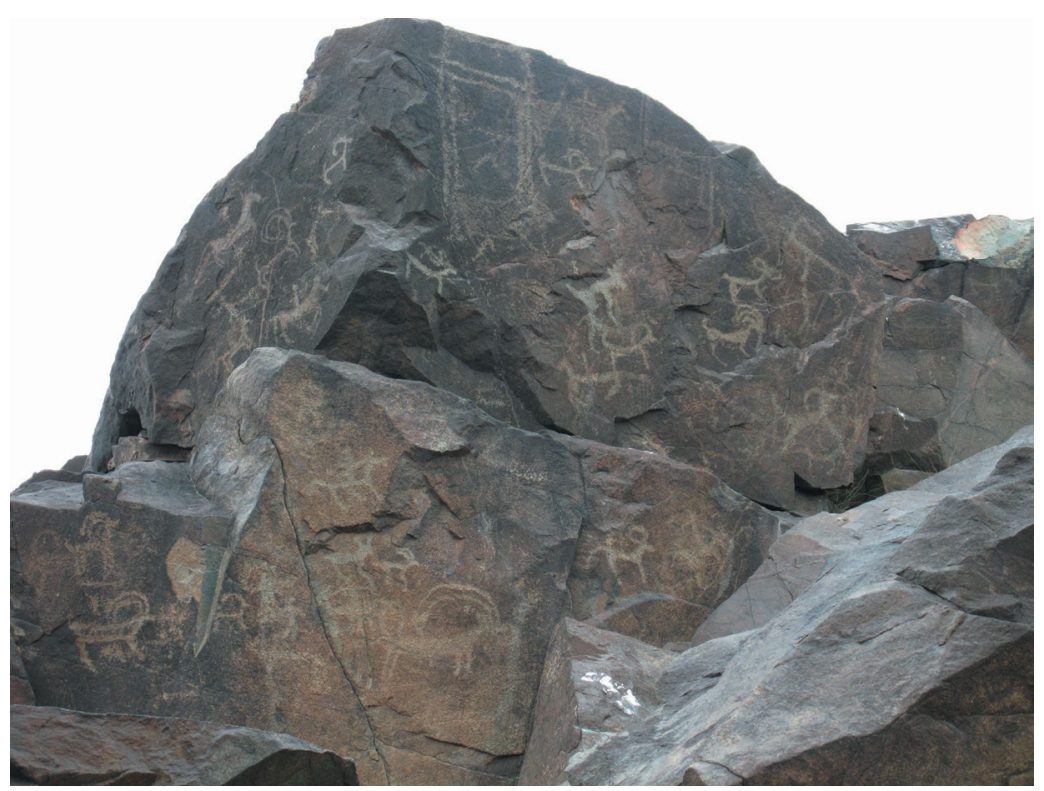

Fig. 2. Petroglyphs of Inner Mongolia depicting animals (Photographer: Zhang Wenjing)

1991) and Sun Jimin (Chen Zhaofu, Xing Lian, 2010), the petroglyphs of Baichahe depicting a dance and a person's face date date to the middle and late Neolithic period. The petroglyphs with animals and hunting imges refer to the Bronze Age. The petroglyphs with animals and faces of people of Zhenzishan belong to the works of the late Bronze Age before the Iron Age.

Petroglyphs of the middle part of Inner Mongolia are mainly distributed in the Northern part of Daqingshan to Dishanqiu, Shaiertengshan and Langshan. From the east to the west there are petroglyphs of the Chahar Banner of the Ulanchab urban district, petroglyphs of Siziwangqi, petroglyphs of Tuilamamiao and petroglyphs of Shahen Damaoqi of the Baotou urban district, petroglyphs of Guyan Baotou, petroglyphs of Damaoqi, Xinhure Banner and Moligeqishan, petroglyphs of Wulate Zhongqi of the Bayan Nur urban district, petroglyphs of Ulatehouqi, petroglyphs of Dengkou with images of animals, hunting, cattle grazing, people, carriages, symbols, hand and foot prints, traces of animal hooves, people's faces, etc. The main technique of the images is incising.
Petroglyphs of the Western part of Inner Mongolia are mainly distributed in Alashan Youqi, the urban district of Wuhai and Alashan Zuoqi. Petroglyphs of Alashan Youqi are concentrated in the Southeast of the Badain Jaran Desert; among them a group of Mandela rock paintings are present in the largest number. The petroglyphs mostly depict animals, hunting, cattle grazing, carriages, villages, human hand and foot prints, etc. In addition, in the Yabulai cave the petroglyphs of handprints painted with a brick-red pigment have an exceptional feature.

In Alashan Zuoqi, there are petroglyphs of Songzigou, Yingwan and Shuangheshan. These petroglyphs are located in the border zone of the Inner Mongolia Autonomous Region and the Ningxia Hui Autonomous Region, in West Helanshan, they are close to the petroglyphs of Zhongwei Ningxia, so the petroglyphs of this zone and the petroglyphs of Zhongwei Helanshan should belong to the same distribution system.

The main themes of petroglyphs are animals: a sheep, a camel, a horse, etc. In addition, there is also hunting, cattle grazing, foot prints, people's faces, etc. All petroglyphs are equally performed 
in the technique of incising and abrading (Gai Shanlin, Gai Zhihao, 2009).

Zhuozishan is located in the Eastern part of the Ordos plateau, in the north-west there is the Wulanbuhe Desert, in the south-west it is connected with Alashan. Petroglyphs of Zhuozishan are widespread in Zhaoshaogou, Kucaigou, Maoergou, Subaiyingou and others (Gao Rongwan, 1991). They mainly depict a person's face, which is about $80 \%$ of the petroglyphs of the total number, but also there is a horseman, animals and other themes. The technique of images is mainly abrading.

\subsection{Petroglyphs of Ningxia}

Petroglyphs of Ningxia mainly belong to the Eastern Helanshan; petroglyphs of the Western foot of the mountain are widespread in the Alashan Zuzi territory in Inner Mongolia, as was previously indicated in the text. Helanshan is located in the Ningxia Valley, in the northwest, at the Western side of the Tenggeli Desert, from the South to the North it stretches for 300 $\mathrm{km}$, its Western flank is flat, the Eastern flank is steep. Locations with petroglyphs of the Eastern foothills of the Helanshan from north to south are Maizhujing, Jiucaigou, Fanshigou, Baijigou, Baituogou, Helankou, Suyukou, Huihuigou, Siyanjing, Damaidi, etc. Petroglyphs contain mainly such animals as a sheep, a deer, a camel, a horse, a tiger, an eagle, a snake, etc., as well as hunting, a horseman, a person's face and other images. Among petroglyphs of Guidegou, a deer is a classic style of the the Scythians. Petroglyphs with faces of people in large numbers are a distinctive feature of Helanshan, including Helankou, the area with a great number of petroglyphs depicting people's faces. The Baijigou petroglyphs also have a distinctive feature - they are created with the technique of applying a red pigment. Petroglyphs of Halankou, in addition to the petroglyphs of Baijigou, are equally performed by incising and abrading. Some of people's faces are made in the technique of abrading, and petroglyphs of animals are made in the technique of incising (Liang Zhenhua, 1998).

\subsection{Petroglyphs of Gansu}

The Gansu petroglyphs are mainly located in Qilianshan and in the Hexi corridor. Beside the petroglyphs of Wujiachuan of the Jingyuan County in the Northwest direction, there are also petroglyphs of Beishan of the Yongchang County, petroglyphs of Heishan Jiayuguan, petroglyphs of Luzigou and Shidunziliang of the Yumen urban district, petroglyphs of Mazongshan of the Subei Mongol Autonomous County, etc. These are mainly images of sheep, deer and other animals; also there are images of cattle grazing, hunting, carriages, etc. The dominant technique is incising, and some images are engraved (Qiu Zhonglong, 2000). Among them, the Heishan petroglyphs with images of wild bison hunting, camel hunting, hand in hand dancing, etc. have an exceptional feature, an exquisite representation.

\subsection{Petroglyphs of Qinghai province}

The petroglyphs of Qinghai are mainly concentrated in the Hainan Tibetan Autonomous Prefecture and the Haixi Mongol and Tibetan Autonomous Prefecture, in the central part and in the northern part of Qinghai Province. The places with petroglyphs are located in Eniugou, Lushan, Shebuqi, Bali, Halong, Huaitoutala, Zhongbutan, Helimu, Ceji, Haixigou, etc. (Su Beihai, 1994) (Fig. 3). The main technique is abrading, and part of petroglyphs is depicted by engraving. The main themes of rock paintings are still animals, among which a yak is predominant - almost each petroglyph depicts a yak, and also there are deer, camels, eagles, horses, sheep and other animals. Petroglyphs of hunting, cattle grazing are also among the main themes, and the object of hunting 


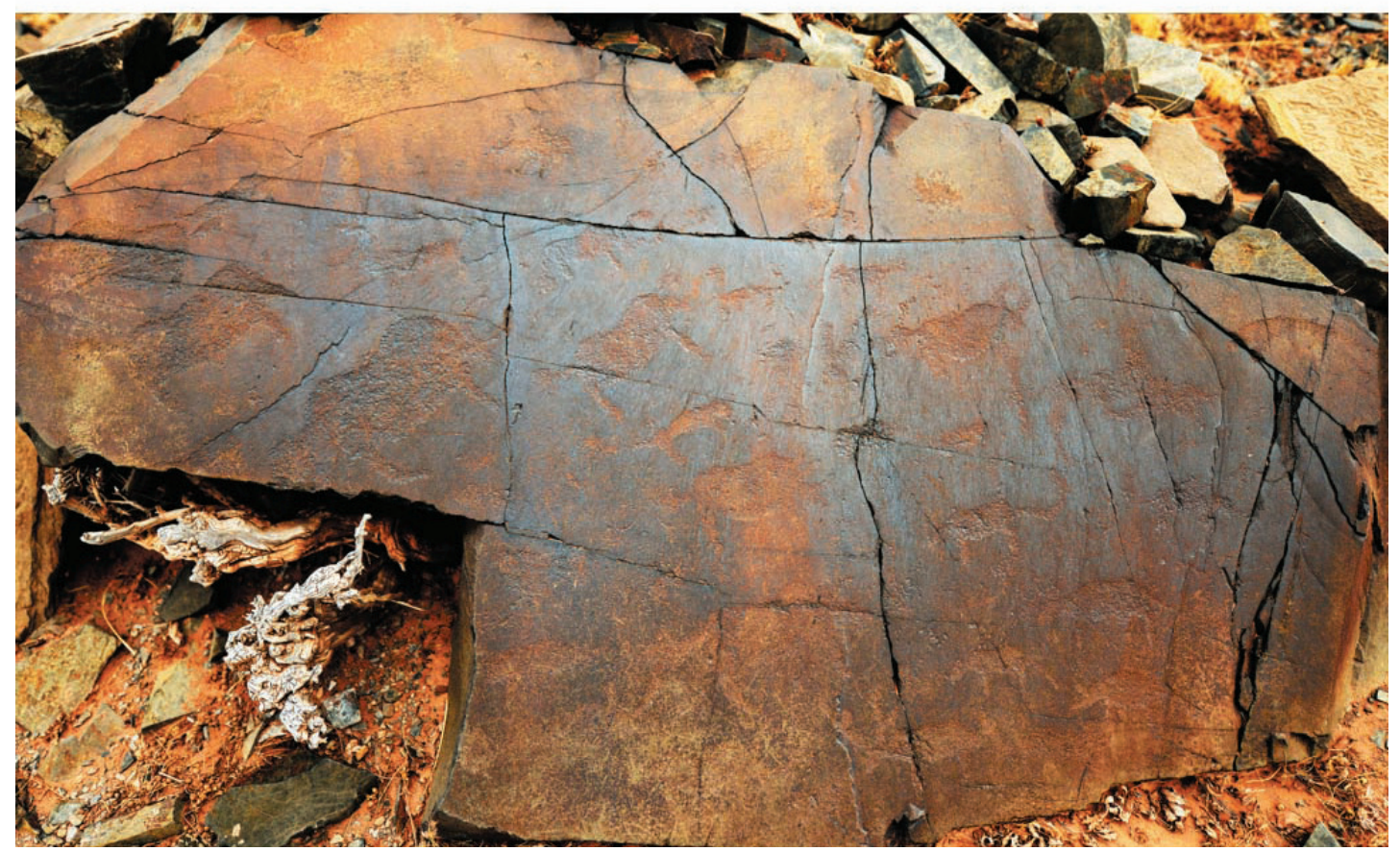

Fig. 3. Petroglyphs of Qinghai province (Photographer: Zhang Wenjing)

is a yak or a tiger. An image of a tiger and its prey also appears in petroglyphs of Qinghai.

Petroglyphs of Lushan depict a deer, a classic manifestation of the Scythian style (Fig. 4).

A carriage in petroglyphs has a distinctive feature, a cart with a pair of wheels and one shaft. The horses are engraved in profile standing up on both sides. Among them, there is a hunter standing on the carriage depicted on two petroglyphs, he holds a bow and arrows in his hands aiming at a yak standing behind the carriage.

\subsection{Petroglyphs of Xinjiang}

Petroglyphs of Xinjiang are mainly located in the Altai Mountains, the Tian Shan Mountains, and the Kunlun Mountains. In the Altai region of the Northern part of Xinjiang there are painted petroglyphs in the Aketasi cave of the Altai city, petroglyphs of Habahe, petroglyphs of Jimunai, painted petroglyphs of the Tangbaletasi cave of the Fuyun County and other areas with petroglyphs. This area is rich with painted petroglyphs, the theme of which refers to animals, handprints, female

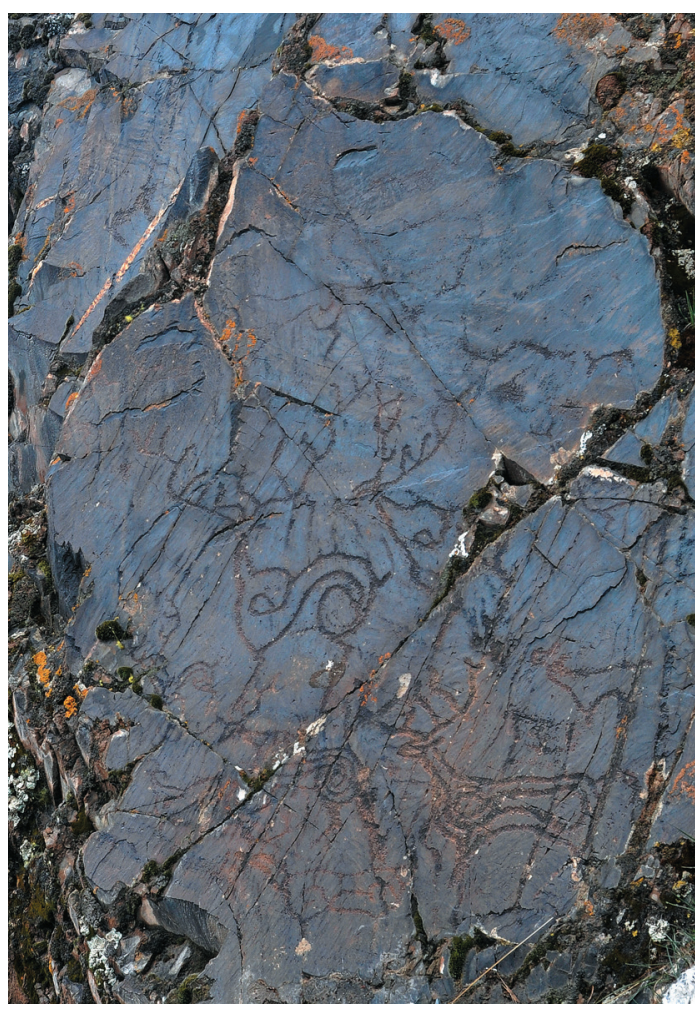

Fig. 4. Petroglyphs of Qinghai Province depicting a deer (photographs are provided by the Yushu Museum of Qinghai Province) 
genitalia, human faces, dancers, hunting, etc.There is representation of such animals as sheep, horses, camels, cows, deer, etc. In the Tangbaletasi cave of the Fuyun County there is an image of a man, a hunter with a bow and arrows and a horseman dancing hand in hand (Sun Jiming, 1994).

In the Tian Shan Mountains and its spurs the placement of petroglyphs is extremely dense; among them the territories of their distribution are Tacheng, Changzhi, Hami, Turpan and the Bortala Mongol Autonomous Prefecture. The main technique is incising; locations with petroglyphs are Yumin, Tuoli district of Tacheni etc. The main themes of these petroglyphs are hunting, cattle grazing, images of sheep, cows, deer, camels, etc. There are repeating scenes of coupling. In such areas as Muleixiang, Qitaixian, Jimusaerxian, Fukangshi, Hutubixian of the Changji Hui Autonomous Prefecture there are petroglyphs of animals, hunting and cattle grazing. Among them, the rock carvings of Hutubikangjia Shimenzi are comparatively expressive; they depict copulating of dancing people, and there is also the image of a man dancing hand in hand and the image of a horse (Tang Huisheng, Zhang Wenhua, 2001). The petroglyphs of the Mori Kazakh Autonomous County depict hunting; among places with petroglyphs in the Hami region there are petroglyphs of Shangmai Hami, petroglyphs of Balikun Lanzhouwanzi and petroglyphs of Dahei, petroglyphs of Tuhuluxiang of the Yiwu County, etc. The themes include hunting, cattle grazing, war, animals, etc. Among the animals there are many images of a mountain goat, a deer, a camel, a horse, a cow, etc. The Tian Shan Usunshanaketasi of the Tekes County is the area of distribution of painted petroglyphs.

Petroglyphs of the Kunlun area are mainly concentrated in the Guma County and the Cherchen County. Locations with petroglyphs in the Cherchen County are Sangzhu, Kanazi, Suleazi and others. The themes refer to hunting, animals, symbols, handprints, etc. Among the animal images, the image of a sheep is the main one, particularly in the petroglyphs of the Cherchen County. The petroglyphs with symbols mostly depict a triangle and rhombic pattern, a net pattern, as well as a whirlpool pattern, etc.

\subsection{Petroglyphs of Tibet}

Tibetan petroglyphs are mostly distributed in the Northern part of Tibet. The Rutog County of the Ngari Prefecture, the Namzo lake coast and the Dangra-yum-tso Lake of the Nagqu Prefecture are the areas of greatest concentration of petroglyphs. Placements of petroglyphs in the Ngari Prefecture are Ladake, Renmudong, Lu Rilangka, Takangba, Kangbarejiu, Zuoyonghu, Zhada and others. The main themes of petroglyphs are hunting, towers, horse riders, animals, symbols, figures, etc. Among the animals there are yaks, deer, eagles and others, among the symbolic petroglyphs the most special ones are the symbols of the swastika that reflect the characteristics of the local religion. Petroglyphs often use the technique of incising; only the petroglyphs of Qunaerqiang used the technique of painting. Placements of petroglyphs in the Nagqu Prefecture are mainly the Damxung county, the Western island of Daxiaozha, the Northern shore of the Namzo Lake, the counties of Lamoduo, Shengza, Wo Zhazhi, Lacuolongba, Nyima, the villages of Zhakun Zibo, Wenburongma, Jialing mountain and others. Petroglyphs of Nagqu are mostly located in caves and are made by applying paint. Also, there is a certain amount of petroglyphs that were made by incising, for example, in the mountains of Jialing, Dangra-yum-tso Lake Area. The main themes of petroglyphs are animals, hunting, sacrification, wars, symbols, towers, figures, etc., among animals there are cows, horses, sheep, deer, tigers, leopards and others, the symbolic petroglyphs are mostly swastikas (Wang Binghua, 1991). 


\section{Petroglyphs of the southwest}

Petroglyphs of the southwest are mainly distributed in Sichuan, Guizhou, Yunnan, Guangxi and other places. Therefore, the petroglyphs of these places were attributed to the petroglyphs of the southwest, mainly due to the fact that the content of petroglyphs found in these places is basically the same. These are mainly the figures of people in religious events; the technique is, most often, red painting. The petroglyphs are mostly located on a dike along the banks of the Yangtze River, etc.

\subsection{Petroglyphs of Sichuan}

Petroglyphs of Sichuan are mainly the petroglyphs of the Matanba burial places in the Gong County. Petroglyphs are created by applying red paint; most of them are human figures, horses, rhinos, tigers, fish and other animals, stables and symbols, etc.

\subsection{Petroglyphs of Guizhou}

Petroglyphs of Guizhou are mainly the petroglyphs Mamai, Kai Yang Huamai, Changshun Fujiayuan of Guanlin County. The main theme of petroglyphs of Mamai is horses, the technique is painting with reddish-brown color; the themes of petroglyphs of Huamai are horses, cranes, birds, fish, sun, trees, horsemen, dancers, etc., the technique is painting with reddish-brown color; the content of petroglyphs of Fujian mainly refer to horses and riders, also there is hunting, scenes of everyday life (houses, etc.) and others, the technique of creation is painting with red-brown color.

\subsection{Petroglyphs of Yunnan}

The main locations of the Yunnan petroglyphs are Jingshajiang and Cangyuan. Petroglyphs of Jingshajiang are located in Zhongdian County, Lijiang County, Ninlan County of the Yunnan Province and in other regions, more than 30 petroglyph locations have been found in total (Chen Zhaofu, 1991). Among them, the Kangsangke petroglyphs are well preserved, the content is also very classical. The main theme of the Jingshajiang petroglyphs is wild animals; the focus is made on a bison image created by engraving. In petroglyphs of Lijiang, the figures of huge cows and other animals are engraved in Dongliangcun Puqilishan. Some scientists believe that the Jingshajiang petroglyphs mainly show wild animals, and there are not that many human figures, so these petroglyphs, perhaps, are the Yunnan petroglyphs of the early period (Chen Zhaofu, 2008). Another important area for the Yunnan petroglyphs is in the villages of Mengsheng and Menglai of Cangyuan-Wa Autonomous County, 10 locations in total. The technique of creation is painting using red iron ore as paint. The main theme is hunting, but there are also dances, housing, villages, trees, handprints, wars and other subjects. A classic feature of the Cangyuan petroglyphs is the engraving of many figures of people. Among them, dances with a shield, a stamp mill and a mortar as musical instruments, heads with a stuck feather and other habits and customs that have been preserved by the peoples of Wa and Dai to this day.

\subsection{Petroglyphs of the Zuojiang basin in}

\section{Guangxi}

Petroglyphs of the basin of the Zuojiang basin in Guangxi are located in the counties of Ningmin, Chongzuo, Pingjiang, Fusui, Daxin and others, there are more than 80 locations in total. All the drawings were created by applying red-brown paint, also many petroglyphs were painted on the cliffs in the river bends, and usually the distance to the water is $20-40$ meters (Fig. 5). The main theme is a human figure that makes up almost 95 $\%$ of the total number of petroglyphs. The created figures of people are simple, there are two poses: en face and in profile, the highest human figure 


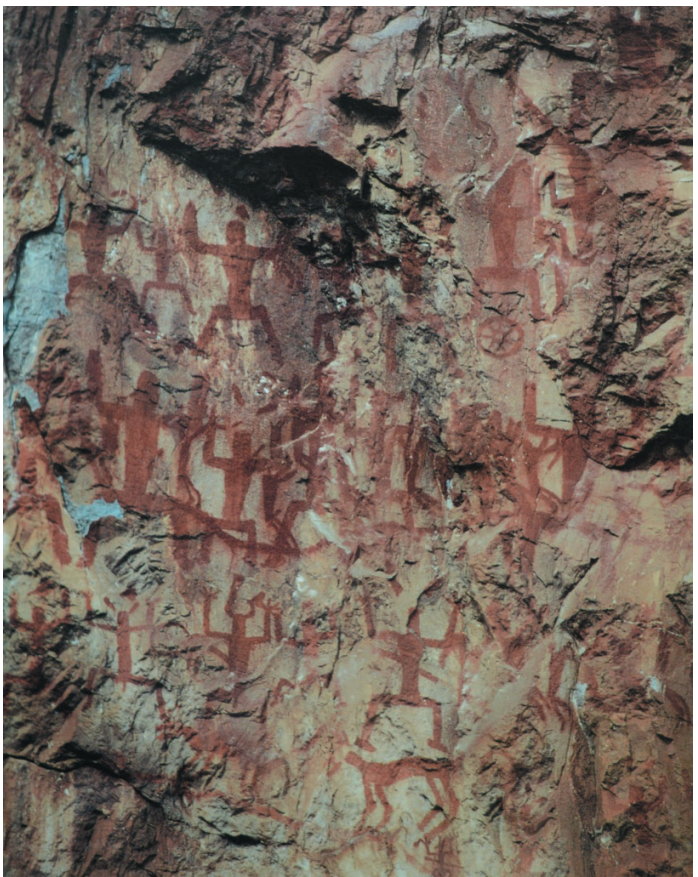

Fig. 5. Petroglyphs of Huashan, Guangxi Province, depicting sacrification (Edited by Jin Weinuo: Fine Arts of China, Huangshan Publishing House, 2010 edition)

is almost 3 meters, the smallest is only $30 \mathrm{~cm}$, the height of most people's images is $60-100 \mathrm{~cm}$ (Zhang Songbai, 1998). Among them, petroglyphs of the Mount Hua of the Ningmin County are the most classic. The images depict a large number of raised hands and legs having the form of the character “出”. In addition, there are also sketches of birds and a copper drum. On July 15, 2016, at the $40^{\text {th }}$ session of the UNESCO World Heritage Committee in Istanbul, Turkey, "the Huashan Rock Art Cultural Landscape" was selected as one of the World Heritage sites and became the $49^{\text {th }}$ World Heritage Site in China. It is the first world heritage site among the rock carvings in China.

\section{Petroglyphs of the southeast}

Petroglyphs of the southeast are located in Guangdong, Fujian, Jiangnsu, Taiwan and Hong Kong and other places. Places of petroglyphs in Guangdong are mainly in Zhuhai - petroglyphs of Gaolan Daobaojingwan, Fujian province petroglyphs of Xianzitang in Hua'an County, in Jiangsu - petroglyphs of Jiangjunya in Lianyungang, as well as engraving on the Wan rock in the Taiwanese city of Kaohsiung. The main technique of these petroglyphs is incising (Fig. 6).

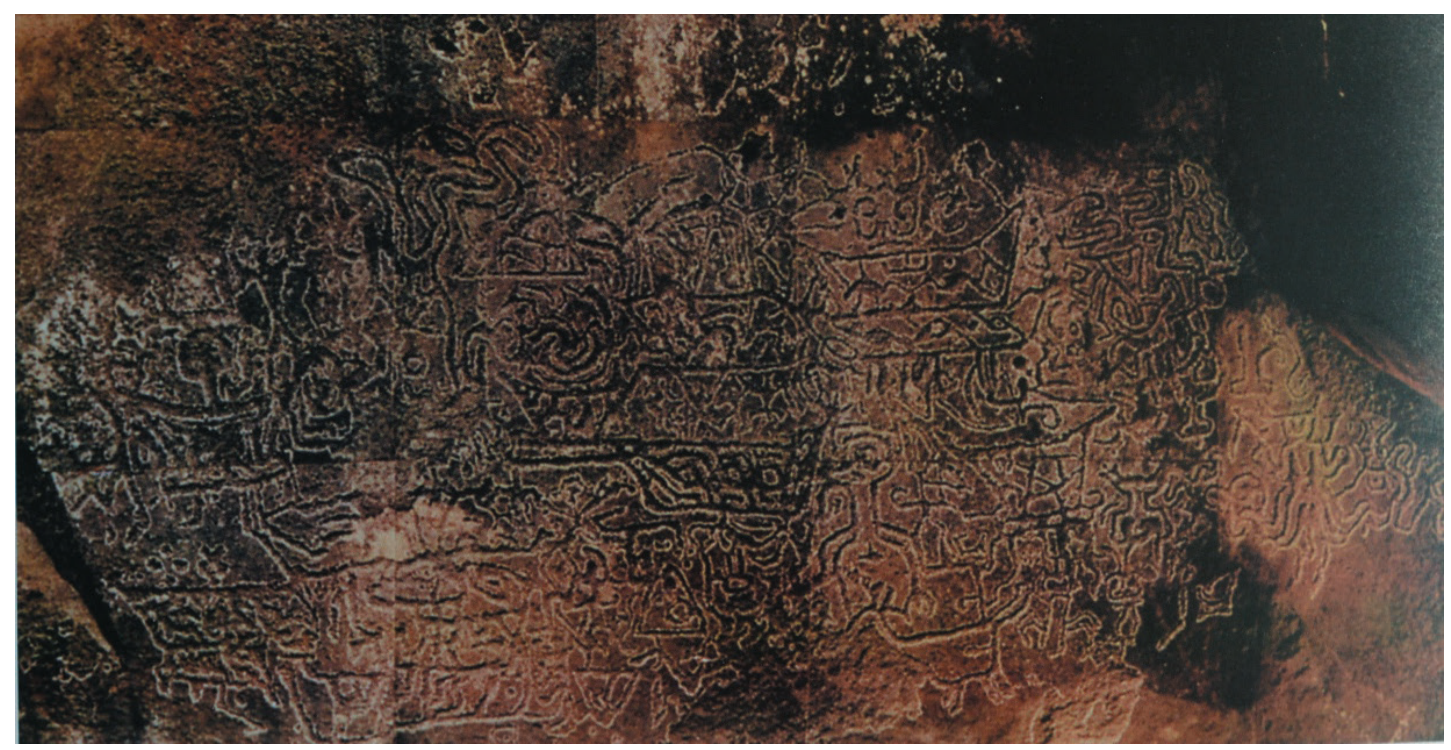

Fig. 6. Petroglyphs of Zhuhai, Guangdong province, depicting people, boats, a totem (edited by Jin Weinuo: Fine Arts of China, Huangshan Publishing House, 2010 edition) 
The main themes of petroglyphs of Baojingwan are boats, waves, people's figures, etc., activities related to sacrification before going to the sea; among the Xianzitang petroglyphs there are images of a human face, dances and others. In other petroglyphs of Fujian there are hoofprints, footprints, hollows, patterns in the form of clouds, etc.; in the Jiangjunya petroglyphs, the engraving of images of human faces is very special, on the image of a human face there are figured outlines, for example: cells, lines, etc., a head portrait is connected by one line to the lower pattern that looks like a plant, in addition, there are also figures in the form of a circle, concentric circles, etc. In other places with petroglyphs in Jiangsu there are also images of ships, hollows, circles, etc. (Liang Zhenhua, 1998: 99-108); The main themes of engravings on the Wan rock are footprints, hollows, images of people's faces, concentric circles, curved lines, etc. Gao Yerong believes that the Taiwan engravings on the Wan rock are closely related to the primitive religion, they have a common cultural tradition (Zhang Yasha, 2006).

In general, since the petroglyphs of the southeast are located in coastal areas, therefore the main content reflects the industrial life of fishermen from the coastal area and religious activities. In addition, the sacrifice to the sea, the sacrifice of the sky and other content of religious activities were more emphasized.

\section{Comparison of three big areas of petroglyph distribution}

Each area of distribution of petroglyphs in China has its own peculiarity. A common feature of petroglyphs in the northern steppe regions is that the main theme is mostly animals, and the technique of incising. The petroglyphs depict mainly cattle breeding and hunting. The nature of the petroglyphs located in the southwest (Yunnan, Sichuan, Guizhou) and other places is very similar, therefore the petroglyphs of this region have common characteristics in terms of content and a technique of creation, so the main content is a person, as well as many activities related to religion. These petroglyphs are painted in red color. Although in the northern petroglyphs there are also painted petroglyphs, for example, petrogyphs in the Alatai, the northern area of Xinjiang, petroglyphs in caves of Nagqu district in Tibet, but their content is mainly animals. The main themes of the first group are animals, handprints, female genitalia, the image of a person's face, etc., the content of the second group is mainly animals, hunting, war, etc. Besides, in Nagqu district, there are many religious factors reflected in petroglyphs: towers' drawings, swastika symbols. Petroglyphs of the southeast are located in coastal areas, and the nature has determined that the content of petroglyphs of this region is associated with the sea. The content of petroglyphs of the southeast is basically symbols, there are waves, concentric circles, there are also boats, people's faces, hoof prints, footprints, etc., this all relates to sacrification before going to the sea. In addition, the petroglyphs of these places are created by a technique of incising.

The above analysis shows that the difference in the petroglyphs of the southwest and the north is that their content and technique are different; besides, the main idea of the petroglyphs in these two regions is different. For the first group, the main theme is a person, the petroglyphs emphasize and reflect various sacrificial activities of the ancient people of the southwestern region, reflect the worship of reproduction, the cult of ancestors, the worship of the water spirit and other ideas; the main content of the petroglyphs of the second group is animals, they reflect life and production of people of the northern regions. The difference in the technique of making petroglyphs of the southwest and the north is very significant, the southwestern petroglyphs 
mainly use a technique of applying red paint, and the northern petroglyphs use mainly the incising technique.

The southeast petroglyphs and southwestern petroglyphs are obviously different in content and technique, but the main idea is similar. The content of the first group is the activity of people covered in paint, in the second group is the incised symbols, the content of petroglyphs mainly reflects religious ideas of people. Of course, such religious ideas of the plea for mercy of God are closely related to the life and activities of people.

The southeast petroglyphs and the northern petroglyphs are similar in technique, but the main content is not exactly the same, besides, the reflected main idea is also different. The content of the southeastern petroglyphs is largely associated with activities when going to the sea: a sacrifice to the sea, a sacrifice to the sky, which reflects religious ideas for the worship of reproduction, worship of the cosmos and the cult of ancestors. The content of the northern petroglyphs, on the contrary, is animals, which mainly reflects the way of life and activity of the northern regions. But this is not at all equivalent to the fact that in the northern petroglyphs there are no petroglyphs associated with religious faith. The images of people's faces on the petroglyphs of Yangshan, Helanshan, petroglyphs with breeding dances in the Xinjiang regions, as well as Tibetan petroglyphs, clearly reflect the cult of ancestors, worship of reproduction and other religious ideas.

In general, the petroglyphs of different regions of China have significant peculiarity. In addition, the distribution of petroglyphs of each region has common features and at the same time have obvious differences.

\section{References}

Chen Zhaofu (2008). Ancient petroglyphs. Beijing, Wenwu Publishing House, 58-62.

Chen Zhaofu (1991). History of petroglyphs in China. Shanghai, Shanghai People's Publishing House, 62-67.

Chen Zhaofu, Xing Lian (2010). Word Petroglyphs: Asia and Africa. Beijing, Wenwu Publishing House, p.19, p.63, 89-90.

Gai Shanlin, Gai Zhihao (2009). A study of petroglyphs of the Great Silk Road. Urumqi: People's Publishing House of Xinjiang, 132-138

Gao Rongwan (1991). Rock carvings of the Wan Rock - a study of rock art first discovered in Taiwan. Taiwan: Dong Publishing House, p.3.

Liang Zhenhua (1998). Petroglyphs of Zhuozi Shan. Beijing, Wenwu Publishing House.

Qiu Zhonglong (2000). Discovery and study of petroglyphs of Zuojiang. Petroglyphs (2nd collection). Beijing, Publishing "Knowledge" House, 31-35.

Su Beihai (1994). Petroglyphs of Xinjiang. Urumqi, Xinjiang Publishing House Meishu Sheying, 25-27.

Sun Jiming (1994). Interpretation of the petroglyphs of Keshiketengqi. In Archeology of Inner Mongolia, (1).

Tang Huisheng, Zhang Wenhua (2001). Petroglyphs of Qinghai - the study of ideas and thoughts of the binary opposition of prehistoric art. Beijing, Scientific Publishing House, 15-63.

Wang Binghua (1991). Petroglyphs representing a cult of reproduction in the Tianshan Mountains of Xinjiang. Beijing, Wenwu Publishing House, 14-16.

Wang Ningsheng (1985). Discovery and study of petroglyphs of Cangyuan in Yunnan Province. Beijing, Wenwu Publishing House, p.125.

$$
-337-
$$


Zhang Songbai (1998). Human petroglyphs of the two banks of the Baicha River. In Archeology of Inner Mongolia, (2).

Zhang Yasha (2006). Petroglyphs of Tibet. Xining, Qinghai People's Publishing House, 30-39.

\title{
Распространение и особенности наскальных рисунков в Китае
}

\author{
Ван Сяокунь ${ }^{\text {a }}$, Чжан Вэньцзин \\ ${ }^{a}$ Китайский народный университет \\ Китай, 100872, Пекин, Хайдянь \\ ${ }^{6}$ Китайская академия рок-музыки \\ Китай, 100031, Пекин, Сичэн
}

\footnotetext{
Что касается системы распространения, наскальные рисунки Китая можно распределить на северные, юго-западные и юго-восточные. В пределах каждого района распространение наскальных рисунков имеет очевидные сходства, и в каждом районе наскальные рисунки имеют свои особенности, отличающиеся от других районов.

Ключевые слова: наскальные рисунки Китая, региональное распределение, сравнение особенностей.

Статья является результатом проекта, спонсируемого китайским университетом Жэньминь для научных исследований. Финансируется специальным фондом для фундаментальных научных исследований в иентральных университетах, номер проекта $18 Y$ ҮА02.
}

Научная специальность: 24.00.00 - культурология, 07.00.00-исторические науки и археология. 